\title{
Sequence Stratigraphy of Well DX, Gongola Sub-Basin, Upper Benue Trough, Nigeria
}

\author{
${ }^{1}$ AMIEWALAN, FO; ${ }^{2}$ BAMIGBOYE, EO \\ *l Department of Geology, University of Benin, Benin City, Nigeria \\ ${ }^{2}$ Department of Geology, University of Port Harcourt, River State, Nigeria \\ *Corresponding AuthorEmail: amiewalanflorence@gmail.com,ebenezer.bams@gmail.com
}

\begin{abstract}
Biostratigraphic study of Well DX has yielded Cretaceous miospores and dinoflagellates cysts which heightened the recognition of sequence boundaries (SB), Maximum Flooding Surfaces (MFS) and associated Systems Tracts. Five maximum flooding surfaces between $95.6 \mathrm{Maand} 89.0 \mathrm{Ma}$, four sequenceboundaries between $96.4 \mathrm{Ma}$ and $93.0 \mathrm{Maand}$ three depositional sequences were identified with varying average thicknesses of sediments interpreted from the gamma ray $\log$ and biostratigraphic data. Thethreedepositional sequencesinterpretedare-depositional sequenceI $(96.4 \mathrm{Ma}-95.4 \mathrm{Ma})(8240 \mathrm{ft}$. - $8120 \mathrm{ft}$.), depositional sequence II (95.4 Ma - $94.0 \mathrm{Ma})(8120 \mathrm{ft}$. - $7850 \mathrm{ft}$.) and depositional sequence III (94.0 Ma - 93.0 Ma) (7850 ft. - $7550 \mathrm{ft}$.). All the depositional sequences fall within the third order cycle. The age of the well was attempted based on the presence of someselected marker fossils - Ephedripites spp., Classopollis spp., Spiniferites spp., Cyclonephelium distinctum, Cyclonephelium vannophorum, Subtilisphaera spp., Eucomiidites spp., Triorites africaensis, Odontochitina costata and Droseridites senonicus recovered from the studied intervals and was dated Albian - Santonian. The Sequence stratigraphic interpretations are useful in further deepening theknowledge of the subsurface geology of the studied well in Gongola Sub Basin, Upper Benue Trough of Nigeria.
\end{abstract}

\section{DOI: https://dx.doi.org/10.4314/jasem.v23i10.14}

Copyright: Copyright (C) 2019 Amiewalan and Bamigboye. This is an open access article distributed under the Creative Commons Attribution License (CCL), which permits unrestricted use, distribution, and reproduction in any medium, provided the original work is properly cited.

Dates: Received: 20 March 2019; Revised: 25 October 2019; 29 October 2019

Keywords: Sequence Boundary, Maximum Flooding Surface, System tracts, Depositional sequence

The studied well was conducted in the Gongola Basin which forms part of the Upper Benue Trough. It has an estimated area of $27,390.25 \mathrm{~km}^{2}$ and lies between longitude $10^{\circ} 42^{\prime}$ '43.8' $\mathrm{E}$ and Latitude $10^{\circ} 07^{\prime} 03.9^{\prime \prime}$ N. Figure 1. Sequence stratigraphy develops as an aspect of stratigraphy that subdivides rock record using a succession of depositional sequences defined as a relatively conformable succession of genetically related strata bounded by unconformities or their correlative conformities. Vail et al., (1977); Van Wagoner et al., (1990). Any package of sedimentary strata bounded above and below by an unconformity (of any kind) is a sequence and hence emphasizes periods of deposition and non-deposition (closely related to episodes of rising and falling sea level) as the essential information. Sequence can be divided into a systems tract and further subdivided into Lowstand Systems Tract (LST), Transgressive Systems Tract (TST) and Highstand Systems Tract (HST), each having a predictable stratigraphic order, shapes and contents. Neal et al., (1993). Sequence stratigraphy is used to analyze the ways sedimentary basins fill, classify strata into a predictive depositional framework for correlation, correlating strata to global sea level, describe the spatial and temporal relationships of a reservoir records. Posamentier and Allen, (1999). The aim of the study is to analyze the ways sedimentary basin fill in well DX, define candidate chronostratigraphic surfaces and classify the strata.

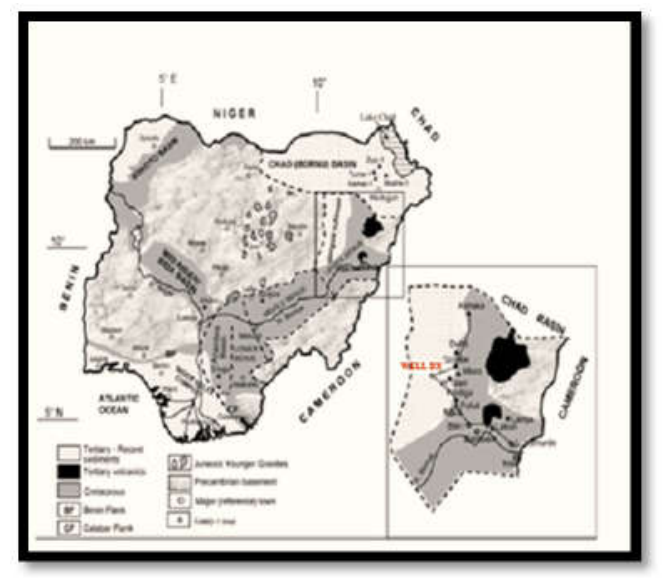

Fig 1: Map of Nigeria showing Area and Locations of Study. (Modified from Obaje et al., 2005)

Geological Setting and Stratigraphy of Gongola Basin: The Gongola basin is a North-South trending Cretaceous basin that links the Benue Trough with the Bornu (Chad) Basin forming part of the West African Rift System. Well DX was drilled in the Gongola Basin in the North-eastern part of Nigeria. The Benue Trough is a fundamental tectonic-sedimentological feature in the Cretaceous and Tertiary geology of 
Nigeria. The trough had been viewed simply as an elongate intracratonic structure of over $1,000 \mathrm{~km}$ long and up to $250 \mathrm{~km}$ at its widest parts, developed as a purely rift structure in the Pan-African mobile belt. Studies published by Benkhelil, (1982), Guiraud et al., (1990) have showed the structure to be a set of pullapart sub-basins or graben generated by sinistral displacements along a pre-existing zone of northeast southwest trending transcurrent faults. The trough has its southern limit at the northern boundary of the Niger Delta, where it dips down and is overlaid with Tertiary and more recent sediments. It extends in a northeasterly direction to the Chad Basin, and is about $150 \mathrm{~km}$ wide. The trough is arbitrarily divided into lower, middle and upper regions, and the upper region is further divided into the Gongola Basin, Yola arms and Lau Basin.

Stratigraphically, the Upper Benue Trough has been presented by several workers - Petters, (1982); Benkhelil, (1982); Obaje et al., (2005). The stratigraphic succession in the Benue Trough comprises essentially thick continental and deltaic sandstones, paralic sandstones, shales, coal measures, and shallow epicontinental shales and limestone. Murat, (1972). The age of the sedimentary rocks in the Benue Trough ranges from Albian to Palaeogene. The stratigraphic succession in the northern segment of the Benue Trough is entirely Cretaceous and starts from the very extensive continental Bima Formation which directly overlies the basement complex. The transitional facies (Yolde Formation), overlies the Bima Formation. According to Falconer, (1911), such transitional formation is between the Muri sandstones and the marine Turonian above it. Cratchley and Jones, (1965) assigned it an "Upper CenomanianLower Turonian" age. The Gongila Formation lies conformably on the Yolde Formation. The Limestone of the Gongila Formation which occurs near the base is rich in fossils that indicate an Early Turonian age. The Pindiga Formation consists of marine shales with Limestones near the base which is fossiliferous and has yielded a lower Turonian fauna age. The contact between the Fika Shale with the overlying Gombe Formation is not well exposed but may be unconformable and this justifies placing the Fika Shales in the Pre-Santonian. The Gombe Formation is thought to rest unconformably on older strata dated late Senonian. The Kerri-Kerri Formation lies unconformably on the folded Cretaceous sedimentations of Paleocene (Tertiary) age. Carter et al., (1963). The Chad Formation unconformably overlies the Fika Shale in some parts of the basin due to non-wide spread occurrence of both the Gombe sandstone and Kerri-Kerri Formation which are mainly restricted to the southwest part of the Basin.
The Formation is a variable sequence that includes all Quaternary sediments of lacustrine origin underlying the surface deposit over a vast area in the Chad Basin. Figure 2 .

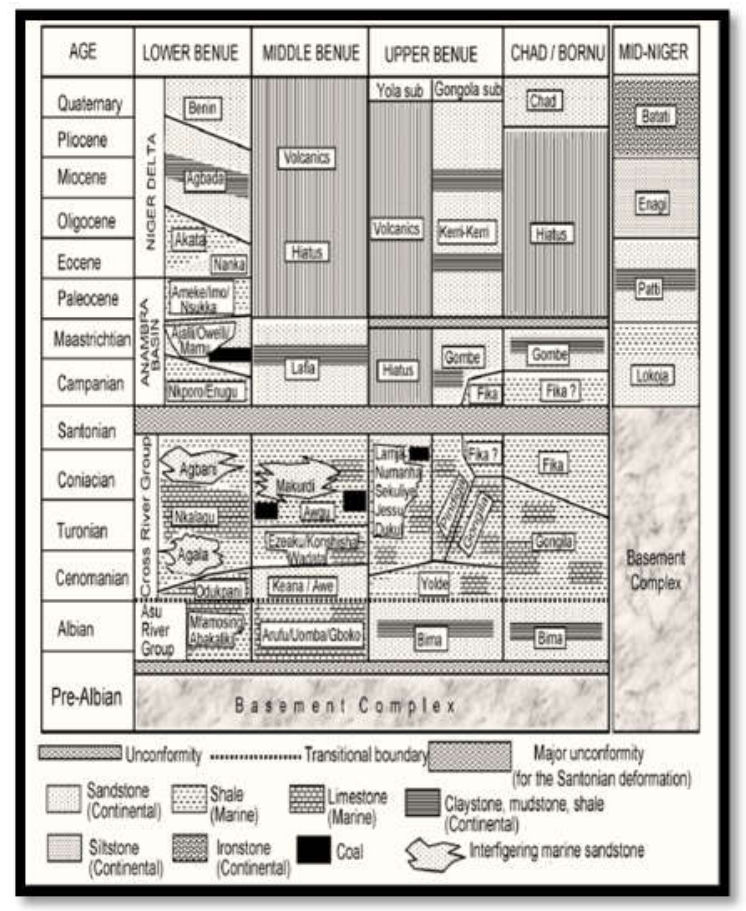

Fig 2. Stratigraphic Successions of the Gongola Basin in Relation to the Benue Trough. (Modified from Obaje et al., 2005).

\section{MATERIAL AND METHODS}

Thirty-five (35) ditch cutting samples with lithofacies of mudstone, sandstone and sandy shale from interval $6980 \mathrm{ft}$ - $-8330 \mathrm{ft}$., gamma ray and resistivity logs were provided by Shell Petroleum Development Company. The method of study includes Palynology slides preparation, interpretation of wireline logs and biostratigraphic data. The processes adopted are outlined below.

Laboratory preparations followed the standard techniques of Phipps and Playford, (1984) of using hydrofluoric $(40 \%)$ and hydrochloric acid (35-38 \%) to digest the silica and carbonates content of the sediments and the release of organic matter from the rock matrix. Heavy liquid separation with zinc bromide, varying degrees of oxidation in $\mathrm{HNO}_{3}$ acid and Schultz's solution to make the palynomorphs translucent for transmitted light microscopy. Residues were mounted on slides using polyvinyl alcohol (PVA) and permanently cure in UV light. Palynology slides were examined using transmitted light microscope (Olympus binocular microscope). 
Biostratigraphic Data: Biostratigraphic data for Well DX comprising of miospore (pollen and spore) and dinoflagellate cysts population diversity were established. The age of the well was attempted based on the presence of some selected marker fossils - Ephedripites spp., Classopollis spp., Spiniferites spp., Cyclonephelium distinctum, Cyclonephelium vannophorum, Subtilisphaera spp., Eucomiidites spp., Triorites africaensis, Odontochitina costata and Droseridites senonicus recovered from the studied interval and was dated Albian to Santonian.

Wireline interpretation: Gamma ray and resistivity log values and signatures of studied well were used to interpret the stacking pattern. These and the lithofacies also assisted in the identification of the various systems tracts, sequence boundaries and maximum flooding surfaces. Mostly, GR is used as common log motif to interpret sedimentary facies of sandstone and mudstone. The GR log represents vertical profile of grain size. The shaly content (radioactivity/shaliness content) increases with higher gamma ray value and decrease of grain size whilst sand has decrease gamma ray value and increase grain size.

Sequence Stratigraphic Analysis: Well log sequence stratigraphic analysis and interpretation was carried out using the abundance and diversity of palynomorphs, wire line logs, their associated system tract and the Global Sea Level chart, Hardenbol, et al., (1998) as a standard guide. Biostratigraphic information was marked on the well $\operatorname{logs}$ so that chronostratigraphic surfaces were refined to ensure that the candidate maximum flooding surfaces corresponded to shaly zones while sequence boundaries corresponded to sandy zones on the well logs. There are three leading schools of thought on sequences, namely: Exxon School (1977-1988), Galloway School (1989) and Emery School (1993). However, the school of thought on sequences by Emery (1993) was adopted in this study. The Emery school is a model of transgressiveregressive (T-R) sequences. Here, the sequences is bounded by subaerial unconformities and maximum regressive surfaces with two systems tracts. The transgressive systems tract lies between the sequence boundary at the base and the maximum flooding surface at the top while the highstand systems tract lies between the maximum flooding surface at the base and the sequence boundary at the top. The sequence stratigraphic framework proposed was correlated with Haq et al., (1988) to delineate the cycle order. (Table 1).

\section{RESULTS AND DISCUSSION}

Age subdivision: Biostratigraphic results from Well DX positioned a broad constraint on the age of the studied well.
The age subdivision were established using key marker palynomorphs based on already published ranges of palynostratigraphically important taxa such as Ephedripites spp., Subtilisphaera spp., Classopollis spp., Spiniferites spp., Cyclonephelium distinctum, Cyclonephelium vannophorum, Eucomiidites spp., Triorites africaensis, Odontochitina costata and Droseridites senonicus.

Albian-Cenomanian Age: Depth interval (7430 ft. $8330 \mathrm{ft}$.). This was based on the regular occurrences of Classopollis spp. and Last Appearance Datum of Ephedripites spp. Assemblages also used to date this section of the well are the occurrences of Subtilisphaera spp., Cyclonephelium distinctum, Cyclonephelium vannophorum, Spiniferites spp., Triorites africaensis and Eucomiidites spp. The above mentioned specimens have been reported by various authors such as Jardine and Magloire, (1965); Moustafa and Lashin, (2012); Herngreen, (1974, 1975); Thusu, et al., (1985); Schrank and Ibrahim, (1995); Lawal and Moulade, (1986) from AlbianCenomanian sediments.

Turonian Age: Depth interval (7280 ft. - $7430 \mathrm{ft}$.). The boundary between the Turonian and Late Cenomanian was established by the first appearance datum of Odontochitina costata. This specimen have been described by Moustafa and Lashin, (2012) to age date Turonian sediment in western desert, Egypt.

Coniacian-Santonian Age: Depth interval (6980 ft. $7280 \mathrm{ft}$.) was marked by the last appearance datum of Droseridites senonicus. This is equivalent to the age recorded by Jardine and Magloire, (1965); Lawal and Moulade, (1986).

Sequence Stratigraphy: Five candidate maximum flooding surfaces between 95.6 Ma and 89.0 Ma were identified. These are MFS 95.6 Ma, 94.4 Ma, 93.4 Ma, 91.6 Ma and 89.0 Ma at $8180 \mathrm{ft}$., $8030 \mathrm{ft}$., $7640 \mathrm{ft}$., $7340 \mathrm{ft}$. and $7190 \mathrm{ft}$. respectively. Also, four candidate sequence boundaries between $96.4 \mathrm{Ma}$ and $93.0 \mathrm{Ma}$ were identified. These are 96.4 Ma, 95.4 Ma, 94.0 Ma and $93.0 \mathrm{Ma}$ at $8240 \mathrm{ft}$., $8120 \mathrm{ft}$., $7850 \mathrm{ft}$. and $7550 \mathrm{ft}$. respectively. Based on the geologic ages of sequence boundaries, maximum flooding surfaces interpreted and using the concept of Emery (1993), three depositional sequences were recognized. These are-depositional sequence I (96.4 Ma - 95.4 $\mathrm{Ma})$ at (8240 ft. - $8120 \mathrm{ft}$.), depositional sequence II $(95.4 \mathrm{Ma}-94.0 \mathrm{Ma})$ at $(8120 \mathrm{ft}$. $-7850 \mathrm{ft}$.) and depositional sequence III (94.0 Ma - 93.0 Ma) at (7850 ft. - $7550 \mathrm{ft}$.) while four genetic sequences were recognized using Galloway, (1989) concept. These are genetic sequence I(95.6 Ma - $94.4 \mathrm{Ma})$ at $(8180 \mathrm{ft}$ - $8030 \mathrm{ft}$ ), genetic sequence II (94.4 Ma - 93.4 Ma) at (8030 ft. - 
$7640 \mathrm{ft}$.$) , genetic sequence III (93.4 Ma - 91.6 Ma) at$ (7640 ft. - $7340 \mathrm{ft}$.) and genetic sequence IV (91.6 Ma - $89.0 \mathrm{Ma})$ at $(7340 \mathrm{ft}$. - $7190 \mathrm{ft}$.). (Table 1). All these sequences fall within the third order cycle of Haq et al., (1988).

Maximum Flooding Surface (MFS): A surface of deposition at the time the shoreline is at its maximum landward position (i.e. the time of maximum transgression). Posamentier \& Allen, (1999). The maximum flooding surface caps the transgressive systems tract and marks the turnaround from retrogradational stacking in the transgressive systems tract to aggradational or progradational stacking in the early highstand systems tract. The following criteria were used in the investigated well to infer MFS:

- $\quad$ MFS marks the change in trend from a fining upward trend below to a coarsening upward trend above.

- The MFS were recognized as intervals of high abundance and diversity of dinoflagellate cysts.

- $\quad$ The lithologies were mainly shale

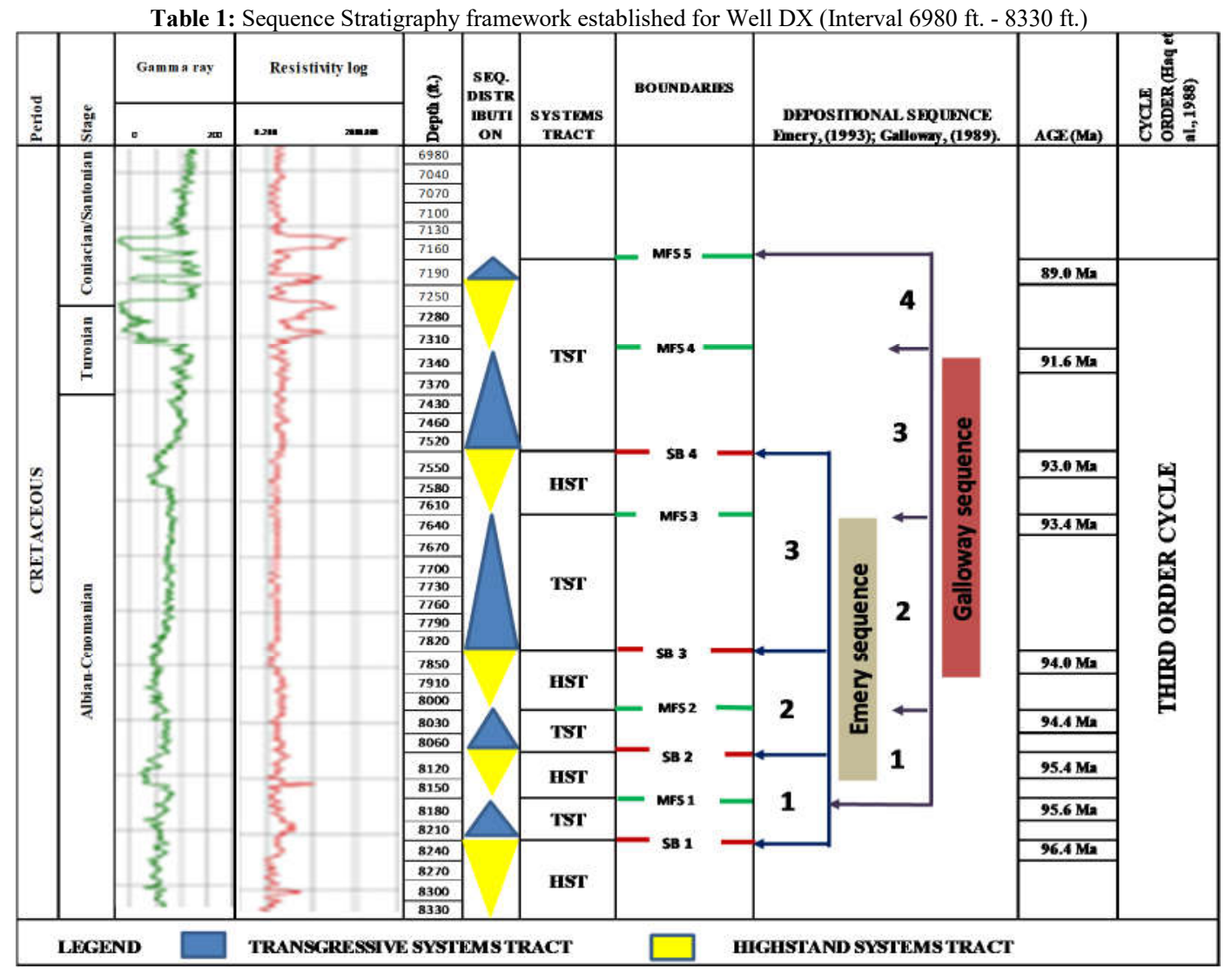

Sequence Boundaries (SB): The sequence boundary is defined as the erosional base of a sand body at the top of the progradational succession characterizing the HST. It is an unconformity in which the surface is exposed, eroded and is used to demarcate different depositional sequence. The four $\mathrm{SBs}$ delineated occurred at $8240 \mathrm{ft}$., $8120 \mathrm{ft}$., $7850 \mathrm{ft}$. and $7550 \mathrm{ft}$. dated 96.4 Ma, 95.4 Ma, 94.0 Ma and 93.0 Ma respectively.

These Sequence boundaries were recognized using the following criteria

- Interval separating the overlying shallow microfacies from underlying deep water facies.

- $\quad$ Minimal biofacies abundance and diversity

- This boundary capped the underlying HST.
Depositional Sequence: The three depositional sequences recognized after Emery, (1993) concept are:

Depositional Sequence I (96.4 Ma - 95.4 Ma) (8240 ft. - $8120 \mathrm{ft}$.): In this sequence, the Transgressive Systems Tract(TST): From $8240 \mathrm{ft}$. $-8180 \mathrm{ft}$. is made up of retrogradational stacking pattern of sandy shale and shale unit capped by a condensed section (MFS) 95.6 Ma at $8180 \mathrm{ft}$. indicated by the abundance peaks of microphytoplankton. The Highstand Systems Tract (HST): From $8180 \mathrm{ft}$. $-8120 \mathrm{ft}$. is made up of shale prograding to siltstone that changed to progradational unit of sandstone overlaid at the top by Sequence Boundary (SB) 95.4 $\mathrm{Ma}$ at $8120 \mathrm{ft}$. The duration range (Ma) fall within the third order cycle. 
Depositional Sequence II (95.4 Ma - 94.0 Ma)) (8120 $f t$. - $7850 \mathrm{ft}$.): The Transgressive Systems Tract (TST): From $8120 \mathrm{ft}$. $-8030 \mathrm{ft}$. is composed of retrogradational stacking pattern of fining upward units with increasingupward microphytoplankton abundance/diversities that are indicative of maximum flooding surface (MFS) $94.5 \mathrm{Ma}$ at $8030 \mathrm{ft}$. The Highstand Systems Tract(HST): $8030 \mathrm{ft}$ - $7850 \mathrm{ft}$. is made up of progradational stacking pattern of sandy unit at the top. The Highstand Systems Tract is terminated at the top by Sequence Boundary (SB) 94.0 Ma defined by barren of microphytoplankton at $7850 \mathrm{ft}$. The duration range (Ma) fall within the third order cycle.

Depositional Sequence III (94.0 Ma - $93.0 \mathrm{Ma}$ )) (7850 ft. - $7550 \mathrm{ft}$.): The Transgressive Systems Tract (TST): From $7850 \mathrm{ft}$ - $7640 \mathrm{ft}$. Consist of fining upward units with great quantity of microphytoplankton that suggests maximum flooding surface (MFS) $93.4 \mathrm{Ma}$ at $7640 \mathrm{ft}$. The Highstand Systems Tract (HST): $7640 \mathrm{ft}$ - $7550 \mathrm{ft}$. is a coarsening-upward profile with sandy unit at the top. The Highstand Systems Tract is covered at the top by Sequence Boundary (SB) 93.0 Ma designated by rarity of microphytoplanktonat $7550 \mathrm{ft}$. The duration range (Ma) fall within the third order cycle.

Conclusion: The presence of some selected marker fossils within the studied interval suggested Albian to Santonian age for the sediments. Five candidate maximum flooding surfaces identified are MFS 95.6 Ma, 94.4 Ma, 93.4 Ma, 91.6 $\mathrm{Ma}$ and $89.0 \mathrm{Ma}$ at $8180 \mathrm{ft}$., $8030 \mathrm{ft}$., $7640 \mathrm{ft}$., $7340 \mathrm{ft}$. and $7190 \mathrm{ft}$. respectively. Also, four candidate sequence boundaries recognized are $96.4 \mathrm{Ma}, 95.4$ Ma, 94.0 Ma and 93.0 Ma at $8240 \mathrm{ft} ., 8120 \mathrm{ft} ., 7850$ $\mathrm{ft}$. and $7550 \mathrm{ft}$. respectively. The three depositional sequences demarcated falls within the third order cycle.

Acknowledgement: The authors are grateful to Shell Petroleum Development Company, Nigeria for providing ditch cutting samples and Wireline logs used for these findings. We also appreciate Mrs. Efe Mude of the Geological services, Shell Petroleum Development Company for her support during the research work.

\section{REFERENCE}

Benkhelil, J (1982). Benue Trough and Benue chain. Geol. Mag. vol. 112, p. 155-168.

Carter, JD; Barber, WM; Tait, EA (1963). The Geology of parts of Adamawa, Bauchi, and Bornu province in N. E. Nigeria, Geol, Surv. Nigeria, Bull. vol. 30, p. 1-99.

Cratchley, CR; Jones, CP (1965). An Interpretation of the Geology and Gravity Anomalies of the Benue Valley, Nigeria. Overseas Geological Surveys,
Institute of Geol. Sciences, London, Geophys. p. $1-26$.

Emery, A. (1993). Transgressive-regressive (T-R) sequence analysis of the Jurassic succession of the Sverdrup Basin Canadian Arctic Achipelago: Canadian Jour. Of Earth Science, vol 30, p. 301320

Falconer, JD (1911). The Geology and Geography of Northern Nigeria. MacMillan, London.

Galloway, WE (1989). Genetic stratigraphic sequences in basin analysis II: application to northwest Gulf of Mexico Cenozoic basin: $A A P G$ Bulletin, vol. 73, p. 143-154.

Guiraud, M (1990). Tectonic-sedimentary framework of the early Cretaceous continental Bima Formation (Upper Benue Trough, NE, Nigeria). Journal of African Earth Science vol. 10 (1\&2), p. $342-353$

Haq, BU; Hardenbol, J; Vail, PR (1988). Mesozoic and Cenozoic chronostratigraphy and cycles of sealevel change. In: Wilgus C.K. et al., (eds.) Sea-level changes: An integrated approach. Spec.

Hardenbol, JJ; Thierry, MB; Farley, PC; Graciansky, Vail, PR (1998). Mesozoic and Cenozoic sequence chronostratigraphic framework of European basins.

Herngreen, GFW (1975). Palynology of Middle and Upper Cretaceous strata in Brazil Meded. Rijkks Geol. Dienst, vol. 26(3), p. 39-91.

Jardine, S; Magloire, L (1965). Palynologie et starigraphie de Cretace des Bassins du Senegal et de Cote d'Ivoire: Mem. B.R.G.M., vol. (32), Coll. Int. Micropol., p 187-245.

Lawal, O; Moullade, M (1986). Palynological biostratigraphy of the Cretaceous sediments in the Upper Benue Basin, N.E. Nigeria. Rev. Micropaleontol., vol. 29(1)

Moustafa, TF; Lashin, GA (2012). Aptian - Turonian Palynomorphs from El-Waha-1 Well, Southwestern Part of the Western Desert, Egypt.

Murat, RC (1972). Stratigraphy and Paleogeography of the cretaceous and lower tertiary in Southern Nigeria. African Geol. Ibadan, p. 251-268. 
Neal, J; Risch, D; Vail, P (1993). "Sequence Stratigraphy - A Global Theory for local success". USA: Rice University, Huston, Texas.

Obaje, NG; Attah, DO; Opeloye, SA; Moumount, A (2005). Geochemical evaluation of hydrocarbon prospects of sedimentary basins in Northern Nigeria. Geochem. J. 40, 227-243.

Petters, SW (1982). Central West African Cretaceous - Tertiary benthic foraminiferal and stratigraphy. Palaeontolographical Abt. p. 1-104, 179.

Phipps, D; Playford, G (1984). Laboratory techniques for extraction of palynomorphs from sediments. Pap. Dept. Geol. Univ. Queensld. 11(1), 1-23.

Posamentier, HW; Allen, GP (1999). Siliciclastic Sequence Stratigraphy: concepts and applications. SEPM Concepts in Sedimentology and Paleontol. 7, 210

Schrank, EC; Ibrahim, MI (1995). Cretaceous (AptianMaastrichtian) palynology of foraminiferal- dated well (KRM-1, AG-18) in the northwestern Egypt, Berliner Geowiss., Abh. Reihe 177, 44.
Thusu, B; Van Der Eem, JGE (1985). Early Cretaceous (Neocomian - Cenomanian) palynomorphs: J. Micropaleontol. (4) (1), 131150 .

van Wagoner, JC; Mitchum, RM; Campion, KM; Rahmanian, VD (1990). Siliciclastic sequence stratigraphy in well logs, cores and outcrops: concepts of high-resolution correlation of time and facies: Am. Assoc. Petrol. Geol., Methods in Exploration. 7. 1-55.

Vail. PR; Mitchum, RM; Thompson, S (1977). Seismic stratigraphy and global changes of sea level, part 3, relative changes of sea level from coastal onlap, in: Payton, C.W. (ed.), Seismic stratigraphy applications to hydrocarbon exploration: Am. Assoc. Petrol. Geol. Memoir 26, 63-97 